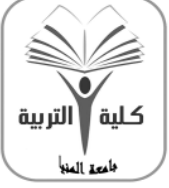

مجلة البعث في التربية وعلم النفس

كلية التزبية - جامعة المنيا

كلية مُعتمدة نن الهيئة القومية لشمان جودة التعليم

\title{
Using a Shadowing Video-Based Program in Improving Prospective Teachers' Teaching Skills and English Language Proficiency
}

\author{
By \\ Shaimaa Ghareeb Ahmed Ali \\ Lecturer of Curriculum and TEFL \\ Hurghada Faculty of Education- South Valley University
}

DOI: 10.21608/mathj.2019.82345

مجلة البحث في التزبية ومام النفس

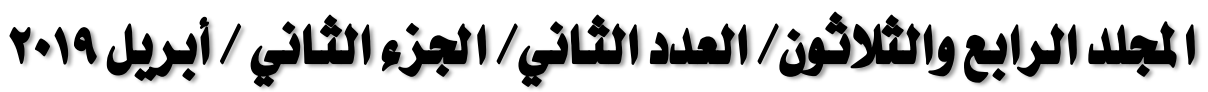

ISSN Print: (2090-0090)

ISSN Online: (2682-4469) 

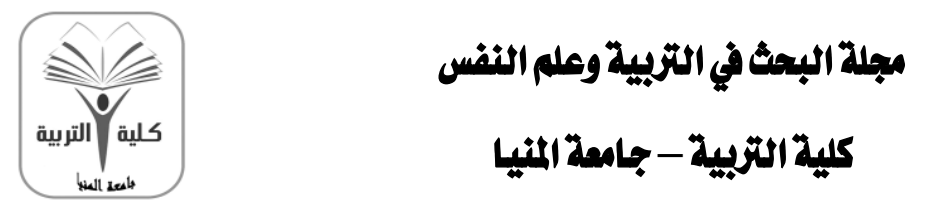

كلية مُتقمدة من الهيئة القومية لضمان جودة التعليم

MINIA UNIVERSITY

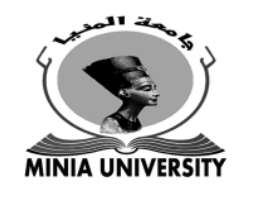

Shaimaa Ghareeb Ahmed Ali

Lecturer of Curriculum and TEFL

\section{Abstract}

Hurghada Faculty of Education- South Valley University

The present research aimed at investigating the effectiveness of using a shadowing video based program in improving prospective teachers' teaching skills and English language proficiency. The study followed the quasi experimental research design of one experimental group and pre/post application of the research instruments. The participants of the research were (30) prospective teachers as an experimental group. The instruments of the research were: a teaching skills observation sheet and an English language proficiency test. The results of the research indicated the improvement of teaching skills and English Language proficiency of the prospective teachers significantly, based on the post results of the observation sheet and the proficiency test compared to the results before using the program and this indicated the effectiveness of this program.. In addition, there is a positive correlatin between the teaching skills and the language proficiency.

Keywords: Shadowing video based program, Teaching skills, English language proficiency 


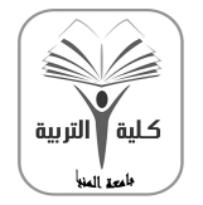

$$
\text { مجلة البجث في التزبية وملم النفس }
$$

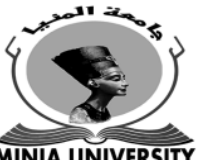

كلية مُتملةةمن الميئة القومية لضمان جودة التمبيم

$$
\begin{aligned}
& \text { مستخحلـص }
\end{aligned}
$$

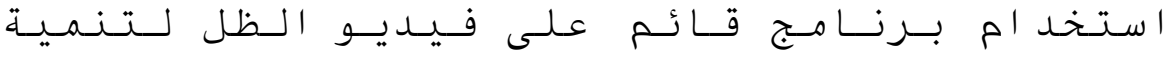

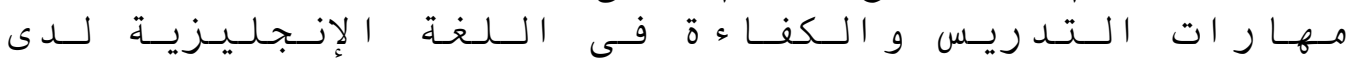

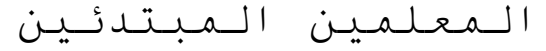

$$
\begin{aligned}
& \text { إعداد } \\
& \text { شيماء غريب أحمد على عبيد }
\end{aligned}
$$

مدرسى بقشم المناهج وطرق التلدريس، كالية التربية بالفرديخة، جامعة جنوب الوادى

هلف البحث الحالي إلى التعرف على فعالية استخلام برنامج قائم على فيديو الظل لتنمية

مهارات التدريس والكفاءة في اللفة الإنجليزية لدى المعلمين المبتدئين. واتبع البحث التصميي شبه التجريبي ذو المجموعة التجريبية الواحدة والتطبيق القبلي والبعدي لأدوات البحث. كان المثاركوز في البحث (•r) من المعلميز المبتدئين كمجموعة تجريبية. و تضمنت أدوات البحث: بطاقة ملاحظة مهارات التدريس، واختبار الكفائة فى اللفة الإنجليزية. أشارت نتائج البحث البعلية إلى تتمية مهارات التلديس عند المعلمين المبتدئين بشكل ملحوظ ، كما تحسنت كفاءتهم فى اللفة الانجليزية بناءاً على تتائج بطاقة الملاحظة لمهارات التدريس و اختبار كفائة اللفة الانجليزية مقارنة بتلك النتائج قبل استخدام البرنامج وهذا يشير إلى فعالية هذا البرنامج. كما اشارت النتائج ايضاً إلي وجود علاقة ارتباطية إيجابية بين مهارات التدريس و الكفائة اللفوية. الكلمات المفتاحية : الظل ، مهارات التدريس، الكفائة فى اللفة الإنجليزية برنامج فيليو 

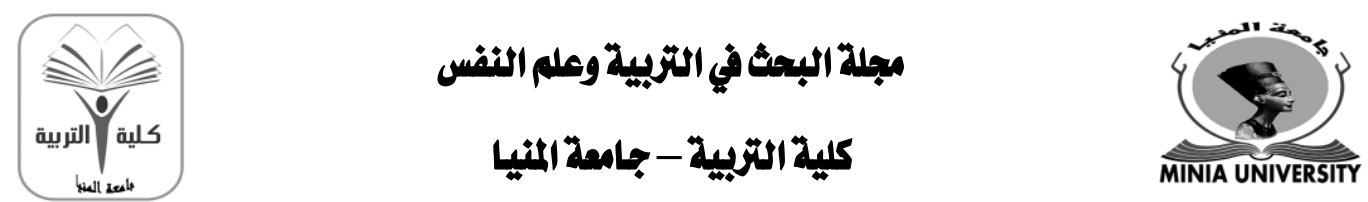

كلية مُعتمدة من الميئة القومية لضمان جودة التمليم

\section{Introduction}

Teachers are important for any educational system. They have a primary role in achieving learning objectives in any course. Accordingly, faculties of education aspire to provide an overall program to support prospective teachers' academic and pedagogical configuration. The success of these faculties is directly correlated with the efficiency of the teaching performance training provided for prospective teachers.

Teachers need a fundamental knowledge and a set of specific skills in order to adequately instruct EFL students. Importantly, Waxman, Tellez, \& Walberg (2005: 2) recommended that teachers need to receive pre-service and professional development training. Fillmore-Wong \& Snow (2000) identified the need for in-service and prospective teachers to develop their knowledge and skills: linguistics, cultural diversity, sociolinguistics, language development, second language learning and teaching, academic discourse, and text analysis and language learning.

A teacher with a poor level of spoken English has difficulty with essential classroom teaching procedures such as giving instructions, asking questions on the text, explaining the meaning of a word or answering a student's question or clarifying vague statements. Cullen (2002: 220) stated that a teacher without the requisite language skills will crucially lack authority and selfconfidence in the classroom, and this will affect all aspects of his or her performance".

Recently, there are challenges to produce a new generation of teachers capable of addressing the demands of the EFL classrooms. Richards (2016) indicated that the poor level of English language teachers is an important issue that has been a concern in teaching the language. Fry (2009) affirmed that "what teachers need is much more robust training and support than they receive today, including specific lesson plans that deal with the high cognitive demands and potential classroom management problems of using student-centered methods".

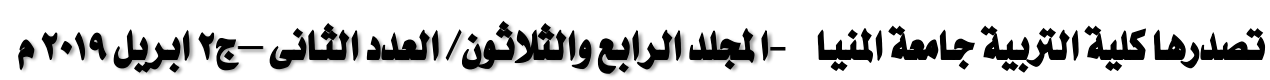



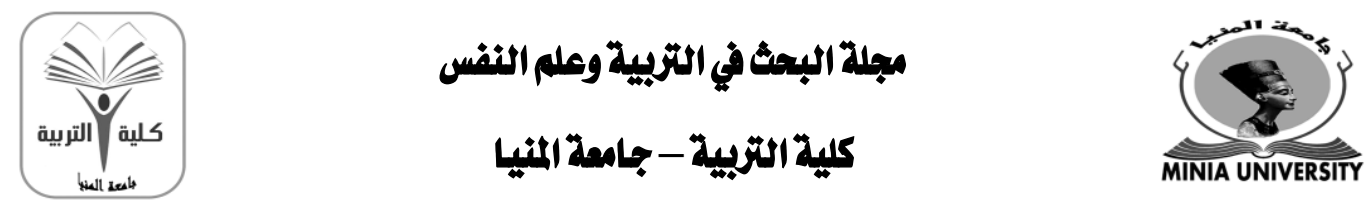

كلية مُعتمدة من الميئة القومية لضمان جودة التمليم

Many studies dealt with teaching skills such as: Taha (2017), Abd El-Gawaad (2016), Hammam (2016), Abd El-Menam (2015), Abu El-Enin (2008), Mansour (2015), Hassan (2008), Gohar (2014). All the previous researches affirmed the urgent need of continuous professional training for EFL teachers adopting new approaches and theories of teaching.

Jennifer \& Collins (2012: 3) declared that "English language prospective teachers need additional training to increase their knowledge, skills, and understanding in designing and delivering effective instruction for students in the classroom". Thus, improving their teaching skill may increase teachers' confidence in meeting the needs of students of language development.

One consequence of the dominant status of English language in many countries is the growing demand for knowledgeable, skillful, and effective teachers of English. Menken \& Antunez (2001) reported that only thirty percent of all teachers have had professional development experiences addressing English language learners needs and issues. Thus, although teachers may have content knowledge, they do not understand the needs of this population and their preparation in appropriate instructional strategies for limited English proficient students is lacking.

Researches of (Butler, 2004; Freeman, 2002; Freeman, 2015; Pennington \& Richards, 2016; Freeman, 2016) reported that "as teachers gain experience in teaching and become more confident in using English to teach, they come to assume an 'insider' identity as a language teacher". Komur (2010) declared that half of the student teachers admitted that they were not proficient enough in the target language and could not teach some grammatical structures effectively because they themselves had problems about them. Al-Mekhlafi (2007) emphasized

Many EFL teachers lack the adequate level of language proficiency and face related difficulties in their professional careers, and he asserted that the development of the candidates' language proficiency skills in English, especially in environments

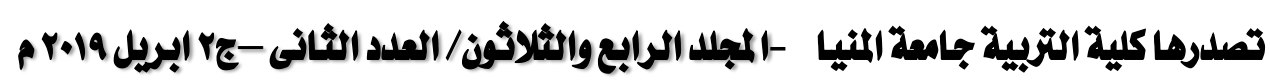

gamel_abdo59@yahoo.com

http://ms.minia.edu.eg/edu/journal.aspx 

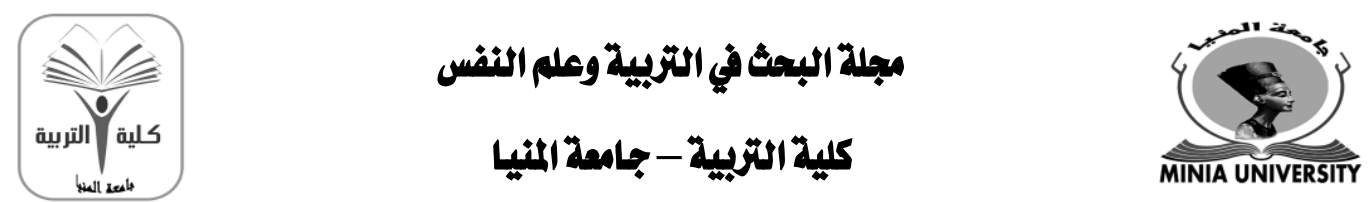

كلية مُعتمدة من الميئة القومية لضمان جودة التمعيم

like Arabic countries where English is a foreign language, should be the most important component of any TEFL program.

Based on the great significance of English proficiency as a major component of content knowledge for EFL student teachers, there should be a continuous training focused and targeted to develop a teachers' language proficiency level.

Consequently, one of the important aspects of training and preparing programs that EFL teachers should have is teaching and language proficiency. Young (2014: 1) stated "For students at the elementary and secondary school levels, access to teachers who have the necessary professional knowledge and functional English language skills to teach English effectively is critical".

Based on what was mentioned above, and in the light of the reviewed literature, the researcher agreed with Tode (2007), Chandler (2003), and Awad (2009) that newer methods of training teachers of English are called for. Shadowing could be one of the new techniques that could achieve effectiveness in English language teaching and learning field until now. Sumarsih (2017) explained that "shadowing was originally used for training interpreters. Shadowing has captured language instructors' attention and been incorporated into teaching a foreign language".

Therefore, the present research was an attempt to investigate the effectiveness of using a shadowing video-based program in improving prospective teachers' teaching skills and English language proficiency.

2. Context of the problem

As a lecturer in EFL curriculum and instruction department, responsible on teaching methodology course and observer prospective teachers in the practical sessions in schools, the researcher observed that prospective teachers showed a low level in teaching skills and English language proficiency. To get more data about the problem of the research, the researcher interviewed ten prospective teachers viewing teaching skills and English language proficiency problems facing them during their teaching practices. The following points have been observed:

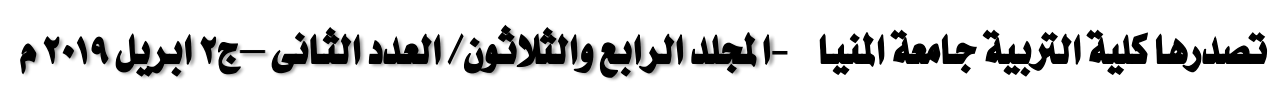



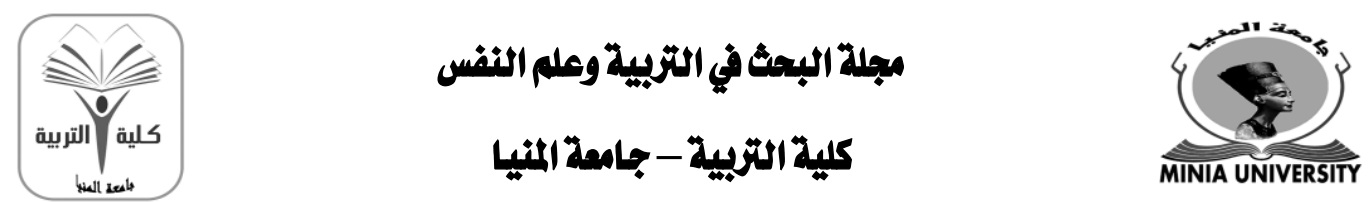

كلية مُعتمدة من الميئة القومية لشمان جودة التمليم

- Eighty percent of the prospective teachers mentioned that they suffered from insufficient practices of teaching skills and English language proficiency.

- Only twenty percent of the teachers stated that they conference their supervisors once a term and mostly to reach an agreed upon the format of a lesson plan and to discuss the appropriate use of a teacher's guidebook along with some formalities.

- All of the teachers assured that senior teachers did not give them advice for developing their teaching practices.

- All of the teachers assured that they lack the ideal models of teaching practices to follow while their actual teaching.

- Seventy percent of the teachers stated that they take notes on the performance of their group members. Yet these notes, mostly take the shape of 'good' and 'bad' performance which intimidates them.

- Thirty percent of the teachers stated that they show low selfconfidence in planning and in presenting a certain skill.

- Eighty percent of the teachers mentioned that their supervisors did not provide them with feedback on their performance.

- All of the teachers mentioned that their supervisors did not give them the chance to re-teach after discussing the performance.

- Seventy percent of teachers express their urgent need to improve their language proficiency level as they didn't feel confident while talking in classrooms.

\section{Statement of the problem}

EFL prospective teachers lack the teaching skills and the English language proficiency. They face problems in finding programs based on shadowing which improve these skills. Therefore the present research investigated the effectiveness of using a shadowing video-based program in improving prospective teachers' teaching skills and English language proficiency.

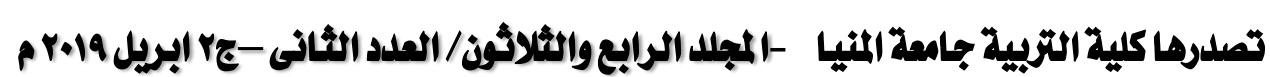




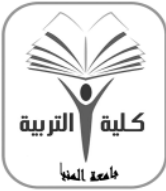

مبلة البعث في التربية وملم النفس

كلية التربية - جامعة المنيا

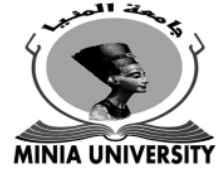

كالية مُعتعدة من الهيئة القومية لشعان جودة التعليم

4. Objectives of the research

The aim of the research was:

1. Investigating the effectiveness of using a shadowing videobased program in improving prospective teachers' teaching skills.

2. Investigating the effectiveness of using a shadowing videobased program in improving prospective teachers' English language proficiency.

3. Examining the statistical correlation between EFL prospective teachers' teaching skills and their language proficiency.

5. Significance of the research

The research could be significant for prospective teachers, teachers of English, pre-graduate students, and course designers:

1. Prospective teachers may benefit from the program in improving their teaching skills and English language proficiency.

2. Teachers of English may benefit from the program in improving their teaching skills and English language proficiency.

3. Pre-graduate students may benefit from the program in improving their teaching skills and English language proficiency.

4. Course designers may benefit in designing a shadowing video-based programs to improve the teaching skills and the English language proficiency.

6. Questions of the research

The research attempted to answer the following main question:

"What is the effectiveness of using a shadowing video-based program in improving prospective teachers' teaching skills and English language proficiency?"

This main question could be branched into the following sub-questions:

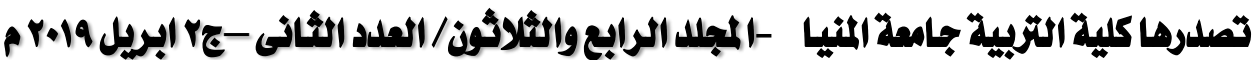

gamel_abdo59@yahoo.com

http://ms.minia.edu.eg/edu/journal.aspx 

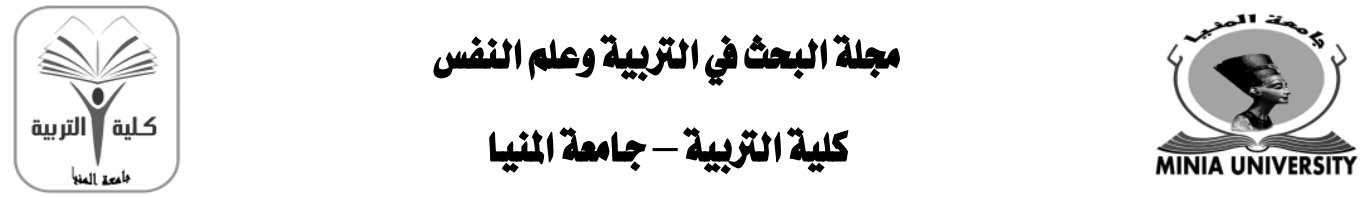

كلية مُقتملةمن الميئة القومية لضمان جودةالتمليم

- What is the effectiveness of using a shadowing video-based program in improving prospective teachers' teaching skills?

- What is the effectiveness of using a shadowing video-based program in improving prospective teachers' English language proficiency?

- What is the statistical correlation between prospective teacher's teaching skills and language proficiency?

7. Hypotheses of the research

The present research tested the following hypotheses:

a) There are statistically significant differences between the mean scores of the experimental group in the pre and post application of the teaching skills observation sheet (in favor of the post application).

b) There are statistically significant differences between the mean scores of the experimental group in the pre and post tests of the English language proficiency (in favor of the posttest).

c) There is a statistically positive correlation between prospective teacher's teaching skills and language proficiency.

8. Delimitations of the research

The study was delimited to:

1. only 30 prospective teachers at Hurghada Faculty of Education.

2. some teaching sub-skills:

Lesson planning skills

$>$ Presentation skills

Classroom management skills

Evaluation skills

3.the first semester of $2018 / 2019$. 

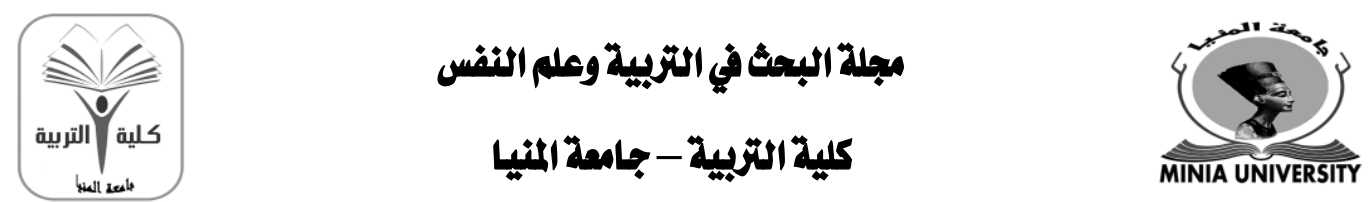

كلية مُعتمدة من الميئة القومية لضمان جودة التمليم

\section{Materials and instruments of the research}

The researcher designed and built a number of materials and instruments for the purpose of the present research:

1. An observation sheet of the teaching skills.

2. An English language proficiency test.

3. A shadowing video-based program.

10. Definition of terms

1. Shadowing video based program:

It is an instructional program that integrates video as an important tool to model teaching practices in an EFI classroom.

2. Teaching skills:

It is a set of performances and activities that done by the teacher, to achieve the objectives of the lesson in EFL classroom.

3. Language proficiency:

It means the mastery of the basic language skills (listening, speaking, reading, writing, vocabulary and grammar), that allow the EFL speakers to use the language correctly and purposefully. 11. Review of literature Teaching skills

Providing teachers with the appropriate tools and strategies to meet student needs is a key demand in preparing teachers to meet the needs of English Language Learners. Educating teachers in the field of appropriate instructional practices to ensure that all learners are learning must not be overlooked. Skilled teachers are needed to help students develop literacy skills for each content area in their foreign language as they simultaneously learn, comprehend, and apply content-area concepts through that foreign language.

Successful teaching skills crucially involve knowledge, decisionmaking and action. Wragg (2005) defined teaching skills as strategies that teachers use to facilitate pupils' learning. He also argues that the skill should be capable of being repeated. He further points out that focusing on particular skills in isolation can be unhelpful because they can become less meaningful out of context.

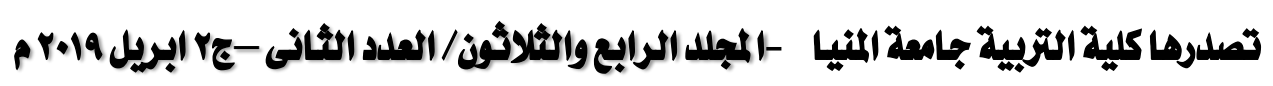



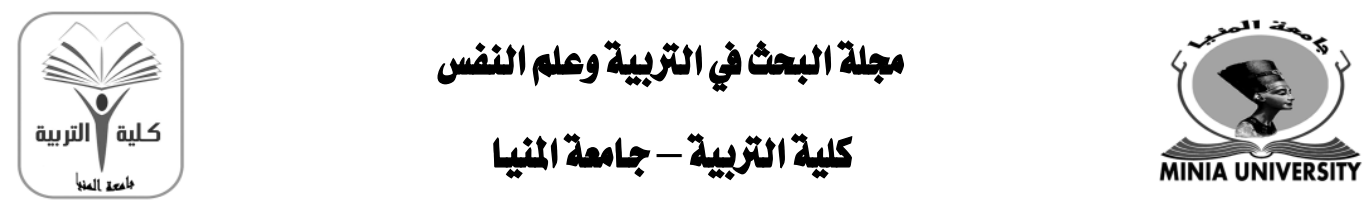

كلية مُعتمدة من الميئة القومية لضمان جودة التمعيم

Kyriacou (2007) defined teaching skills as discrete and coherent activities by teachers which foster student learning. He pointed out that there are three important elements of skills:

- Knowledge: comprising the teacher's knowledge about the subject, pupils, curriculum, teaching methods, the influence on teaching and learning of other factors, and knowledge about one's own teaching skills.

- Decision-making: comprising the thinking and decisionmaking that occurs before, during and after a lesson, concerning how best to achieve the educational outcomes intended.

- Action: comprising the overt behavior by teachers undertaken to foster pupil learning.

Hameeda (2013: 125) identified teaching as the set of teaching activities and processes performed by the student- teacher within the classroom as he explains courses lessons in the light of international standards to improve the teaching and learning process by using teaching strategies to achieve specific goals.

Akinsola (2014: 42) defined teaching practice as a time when all learned theoretical concepts and ideas in educational psychology, management of classroom, subject content, curriculum development, various philosophies dealing with education are called into use.

Gouda (2015: 101) recognized the teaching as a set of behaviors and teaching practices carried out by the teacher during the implementation of the lessons and is characterized by the accuracy and proficiency of performance which assessed according to the following areas: (planning of the lesson - implementation of teaching - classroom management and order maintenance motivation - class questions ( (A) teacher questions / (B) student questions) - personal semantics and human relations - mastery of specialization - teaching and student learning evaluation.

According to Pete \& Fogarty (2015), a measure of 21st century effective teaching behaviors should include being able to 

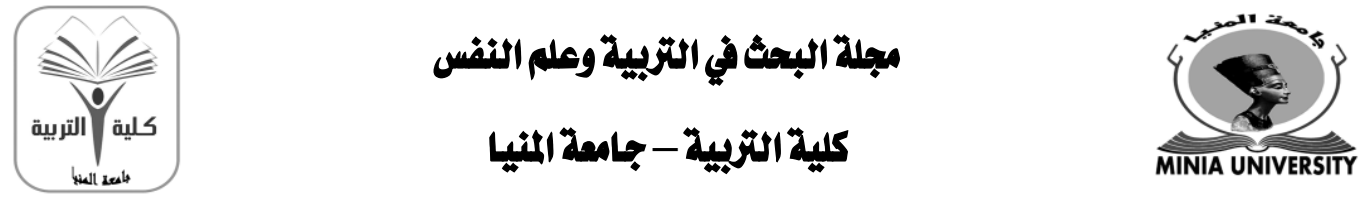

كلية مُعتمدة من الميئة القومية لضمان جودة التمليم

solve problems, taking care and managing self, adapting to change, conceptualizing ideas, analyzing and evaluating, communicating and sharing, collaborating with others, and being ready for change.

Rayan (2018: 316) included a continuum of behaviors expected to be acquired by student teachers for the planning, implementation and evaluation processes. They are expected to: create safe and effective learning environments, bring in use multiple forms of classroom communication skills and take effective measures in order to organize Students Learning.

Mcber (2000) defined teaching skills as are those micro behaviors that the effective teacher constantly exhibits when teaching a class. He identified the following list of teaching skills:

- high expectations

- planning

- methods and strategies

- pupil management/discipline

- time and resource management

- assessment

- Homework

According to Cooper (2011: 6) teaching skills are the specific sets of identifiable behaviors needed to perform teaching functions. Such a repertoire is necessary if teachers are to be effective with students who have varied backgrounds and learning aptitudes. He lists the following skills that facilitate student achievement:

- Completing three- term contingency trials

- Effective use of error correction procedures

- Use of specific, positive and corrective feedback

- Maintaining momentum and effective pacing

- Providing clear presentations including stating goals and main points of the lesson, modeling, prompting and checking for understanding and managing students during set work.

Philpott (2009:1) listed the following teaching skills:

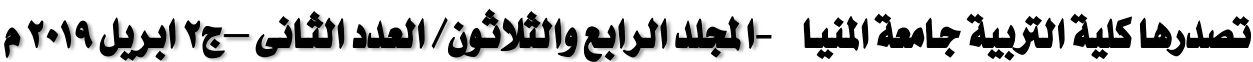



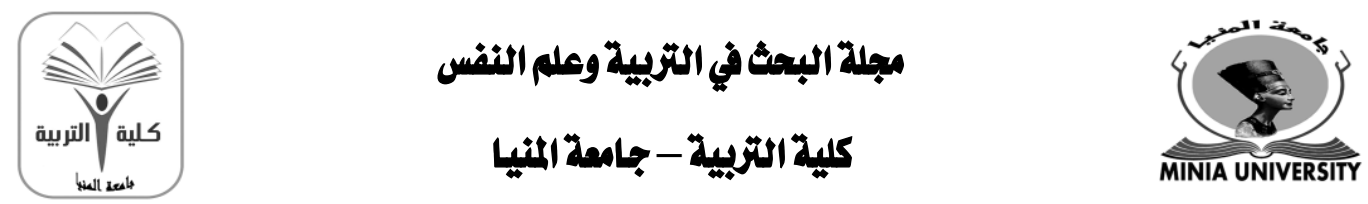

كلية مُعتمدة من الميئة القومية لضمان جودة التمليم

- Enlivening teaching and learning

- Creating independent students

- Encouraging reflective learners' thinking

- Revision

The United Kingdom international organization for educational opportunities and cultural relations (2008) stated the following list of teaching skills:

- Course and lesson planning

- Classroom management

- Learning technologies

- Subject knowledge

- Understanding your learners

Eggen, Kamp \& Kauchak (2009) stated that the essential teaching skills required to create productive learning environments include attitudes, organization, communication, focus, feedback, questioning, review and closure. Bulber, Mohr \& Walls (2002) determined outcomes, clarity, enthusiasm, and engagement as the four aces of effective teaching. In her review of international literature on teacher effectiveness, Hunt (2009) stated knowledge, attitudes, and performance as the major skills needed by teachers.

Reviewing the previous literature, the present research stated the following skills as the needed for EFL prospective teachers:

- Lesson planning skills which included the teachers' ability to set the behavioral objectives of the lesson based on the students' need and the content included in EFL textbook, then drawing a comprehensive plan for a achieving these objectives

- Presentation skills which included all teachers activities and performances that executed in the classroom to achieve learning objectives

- Classroom management skills included the teachers' ability to organize and warm up the learning environment for best teaching practices

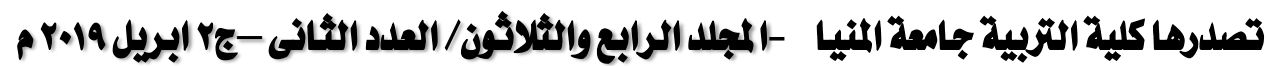



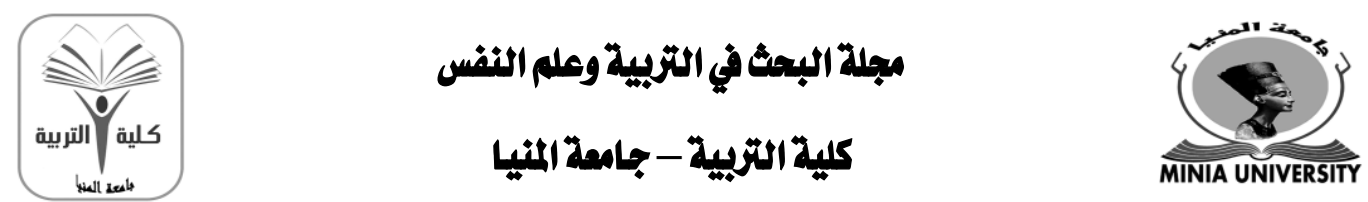

كلية مُعتمدة من الميئة القومية لضمان جودة التمليم

- Evaluation skills included the teachers' ability to check students' achievement and modify their problems and difficulties.

Language proficiency

English language proficiency is the ability of students to use the English language to send and receive messages in spoken and written contexts. It includes four skills: listening, speaking, reading, and writing that should be developed among the students who learn English. Of the four language skills, writing and reading are considered written proficiency, whereas speaking and listening are both considered oral proficiency skills. Stern (1991: 337) stated that language proficiency can be summarized as:

- The initiative mastery of the form of the language;

- The initiative mastery of the linguistic, cognitive, affective and sociocultural meaning expressed by the language forms;

- The capacity to use the language with maximum attention to communication and minimum attention to form;

- The creativity of language use.

The council of Chief State School Officers (CCSSO) (cited in Law \& Eckes 2007: 87) defined the English language proficiency as the ability to use the English to ask questions understand teachers, read materials, test ideas and respond to what is being asked in the classroom. This model of language proficiency declares the students' ability to function in the four language skills of reading, listening, writing and speaking and the need to assess each of these four skills. The Australian Second Language Proficiency Ratings ASLPR) described language proficiency in terms of four macro skills (reading, writing, speaking and listening).

From a different view, Bachman \& Palmer (1996: 60) identified six interrelated areas of language knowledge:

- Organizational knowledge, i.e. the way in which texts are structured; 

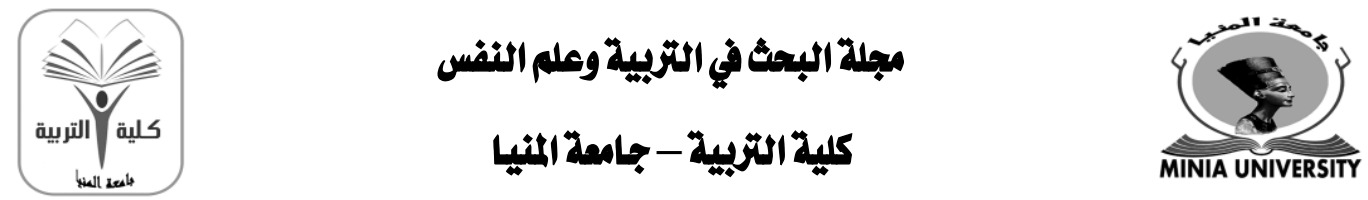

كلية مُعتمدة من الميئة القومية لضمان جودة التمليم

- grammatical knowledge including knowledge of vocabulary, syntax and phonology/ graphology;

- Textual knowledge which includes knowledge of cohesion and knowledge of rhetorical or conversational organization

- Pragmatic knowledge which related to the communicative goals of the language user and the context in which language is being used

- Functional knowledge which includes an understanding of ideational, manipulative, heuristic and imaginative functions, as well as socio- linguistic knowledge.

Canales (1994: 60) defined language proficiency, from a socio theoretical foundation, as:

- It is dynamic and contextually - based (varies depending upon the situation, status of speakers, and the topics),

- It is discursive (requires connected speech),

- It requires the use of integrative skills to achieve communicative competence.

It is clear from the previous review that language proficiency was defined differently by language specialists. However, they all agree that language proficiency is the individuals' ability to express him/ herself freely and in accordance with the conventions of grammar and vocabulary meaning in the foreign language.

Ohio (2010), Shekhtman (2002), Alderson (2006) declared that there are five levels of English language proficiency which are summarized below. It should be recognized that within each of these levels, students may represent a certain range of proficiencies (low, mid, high).

- Pre/functional Learners may understand isolated words (particularly school and social environment vocabulary), some high-frequency social conventions, and simple (single word or short phrase) directions, commands and questions. They can get meaning mainly through pictures. Students also, participate in writing activities by drawing pictures.

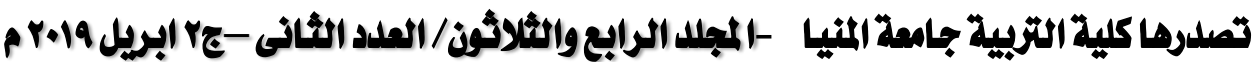




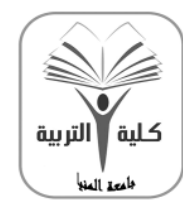

مبلة البعث في التربية وملم النفس

كلية التربية - جامعة المنيا

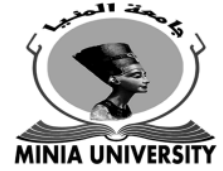

كلية مُقتملة من الميئة القومية لضمان جودة التمليم

They may be able to write letters or form them from memory and are able to write some words.

- Beginning Learners begin to imitate verbalizations by using single words or simple phrases and begin to use English spontaneously. They gradually construct more meaning from the words themselves, but the construction is often incomplete. They are able to generate simple texts that reflect their knowledge level of syntax.

- Intermediate: learners understand more complex speech, but still may require some repetition. They acquire a vocabulary of stock words and phrases covering daily situations. They use English spontaneously, but may have difficulty expressing all their thoughts due to a restricted vocabulary and a limited command of language structure.

- Advanced: learners' language skills are adequate for most dayto-day communication needs. Occasional structural and lexical errors occur. Students may have difficulty understanding and using some idioms, figures of speech and words with multiple meanings. They communicate in English in new or unfamiliar settings, but have occasional difficulty with complex structures and abstract academic concepts..

- Proficient/Trial-mainstream: learners usually can participate in academic topical conversations without difficulty. In their writing, they usually show control of varied sentence structures, spelling and vocabulary, expressing welldeveloped thoughts.

Language teachers have different responsibilities and roles more than other teachers, as they should show an appropriate level of language proficiency to execute their tasks. Many studies affirmed the importance of teachers' language proficiency (e.g, Macalister, (2017); Van (2018); Coniam (2017); Aoki (2013); Tsang (2017), Grsser (2013); Algazo (2012), Çetinavcý \& Yavuz (2010), Al-Mekhlafi (2007), Altan (2006), Banegas (2009)).

\section{Shadowing}

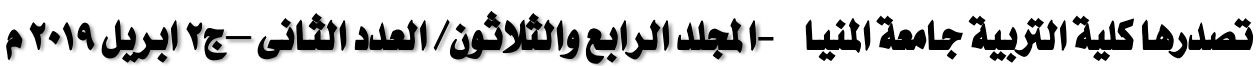

gamel_abdo59@yahoo.com

http://ms.minia.edu.eg/edu/journal.aspx 

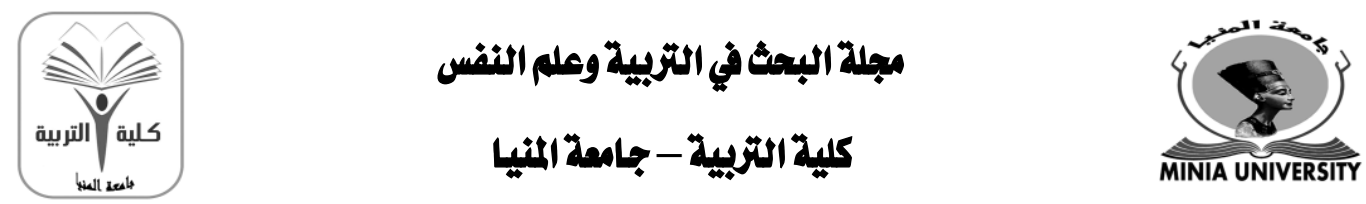

كلية مُقتملةمن الميئة القومية لضمان جودة التمليم

The early research into shadowing was carried out in the field of psychology in the sixties and it was used to train interpreters and continues to be used for that purpose (Mochizuki, 2006). According to Puri \& Treasaden (2009: 180) "the shadowing technique is a particular form of dichotic listening'. Rost \& Wilson (2013) assured that shadowing is the immediate repetition of a source language. Shiki (2010) defined shadowing as the on-line immediate process of repeating speech, while repeating is an off-line task because it provides learners with silent pauses to reproduce the sounds.

Safont \& Compoy (2002: 142-143) stated that shadowing "is repeating a stimulus discourse verbatim as it is being delivered". Shadowing can be also defined as the audible emulation of a certain input as it is received. Hamada (2012: 3) emphasized that shadowing is defined as "an active and highly cognitive activity in which learners track speech they hear and vocalize it as clearly as possible while simultaneously listening".

Related to language learning and teaching, Tamai (1997: 20) defined shadowing as, "an act or a task of listening in which the learner tracks the heard speech and repeats it as exactly as possible while listening attentively to the in-coming information". Wiltshier (2007: 44) stated that "Shadowing is a cooperative learning experience'. Thus, shadowing could be a technique that represent to the language learners the correct input of language and help in avoiding errors.

Obviously, Shadowing could be an interesting way in English language teaching and learning field until now. Hatasa (2011: 294) emphasized that "this technique is found to improve both speaking and listening skills among foreign language learners because it helps them to process information faster. Moreover, Manseur (2015) assured that it is considered as an efficient procedure and one of the best techniques for learning foreign languages.". Jullian (2012) explained how one can improve English speaking and fluency through shadowing. He

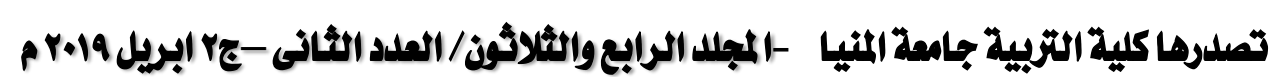

gamel_abdo59@yahoo.com

http://ms.minia.edu.eg/edu/journal.aspx 

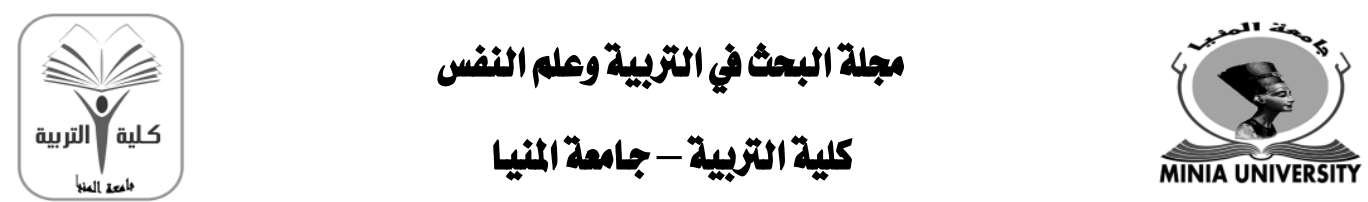

كلية مُعتمدة من الميئة القومية لضمان جودة التمعيم

adds that one of the best features of this technique is that it enables a learner to practice pronunciation and train him/herself to be fluent in speaking even at home. According to Shiki (2010), shadowing is the on-line immediate process of repeating speech, while repeating is an off-line task because it provides learners with silent pauses to reproduce the sounds.

Tanaka (2002) considered shadowing as one of the important techniques used for interpreter training; he also stated that shadowing is effective in developing a good ear for language, specifically in regard to accent and intonation, as well as improving overall listening ability. Sin-wai (2004: 205) defined shadowing as a "technique of listening to a source language message and at the same time repeating what one hears".

Rost \& Wilson (2013: 115) emphasized that "shadowing is a useful technique for students who are very reticent to speak in more open discussion activities". In addition, some researchers have emphasized its role in the improvement of the listening skill. For instance, Snell-Hornby (1994) considered shadowing as an effective exercise that enhances listening concentration. As a result, it has been proved that shadowing develops the listening skill. On one hand, Hamada (2012: 4) stated that "the effectiveness of shadowing on improving listening comprehension skills has been examined in classroom research". On the other hand, Arnold \& Murphey (2013: 177) assumed that "shadowing is also similar to active listening ".

Although shadowing is primarily the repetition of a particular input as it is received, it differs from repetition in many aspects. According to, Shiki (2010), "repeating is considered an offline task in which learners are given silent pauses to reproduce the sounds they have heard; shadowing is considered an online task'. In this sense, shadowing is an online task because it involves some cognitive processes, such as attention, speech comprehension, and speech processing. While shadowing is the online immediate imitation of a particular input, repetition is the offline reproduction of this input using some pauses.

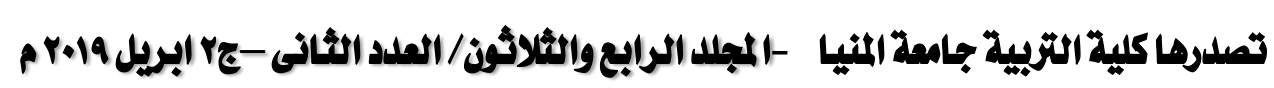



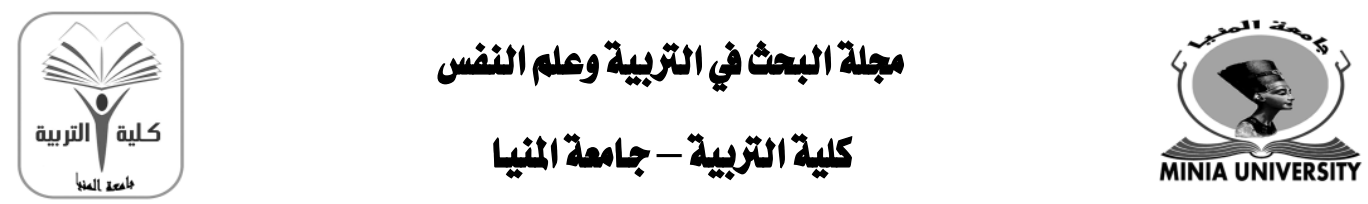

كلية مُعتمدة من الميئة القومية لضمان جودة التمعيم

Shadow in the present research, refers mainly to teachers' teaching video. In classes, teachers carry out teaching by playing teaching video, thus relieving themselves from teaching. At this time, teachers practice the same roles as students and ask questions, seek for clarification. Shadow teaching relieving teachers from teaching provides them with a chance to face up to their own teaching process, while "shadow video" like a model makes it easier for teachers to find out problems in teaching. Moreover, it could be a way to find out language problems and modify their errors.

Obviously, shadowing technique depends on videos either to improve teaching performance or modifying language level. Video has been used in teacher preparation programs since the 1960s. Wang (2008) stated "this tool has been regarded as having the potential to provide a means by which the complexities of teaching might be captured thereby enabling prospective teachers to observe and reflect upon what they are seeing ". Thus, video is regarded as a tool that can help prospective teachers develop the ability to notice and analyze what is occurring in the classroom. Sherin \& Van Es (2005) found that, through the use of video, students involved in their research were able to make more evidence-based comments about teaching.

Perhaps the most compelling feature is the capacity of video to preserve both the verbal and non-verbal elements of a teaching situation. Many researches affirmed the importance of video in improving teaching situation (e.g, Quigley \& Nyquist (1992), Sherin \& Van Es (2005), Snoeyink (2010), Calandra, (2009)). This provides the opportunity for multiple viewing of the teaching situation, enabling the viewer to observe elements and events that occurred in the teaching situation that might otherwise have gone unnoticed (Zhang, 2010).

Advantages of shadowing

There are various advantages of the shadowing technique. Shadowing is believed to be a valuable exercise and efficient technique that helps learners to develop a variety of aspects.

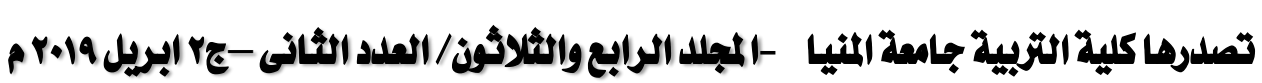

gamel_abdo59@yahoo.com

http://ms.minia.edu.eg/edu/journal.aspx 

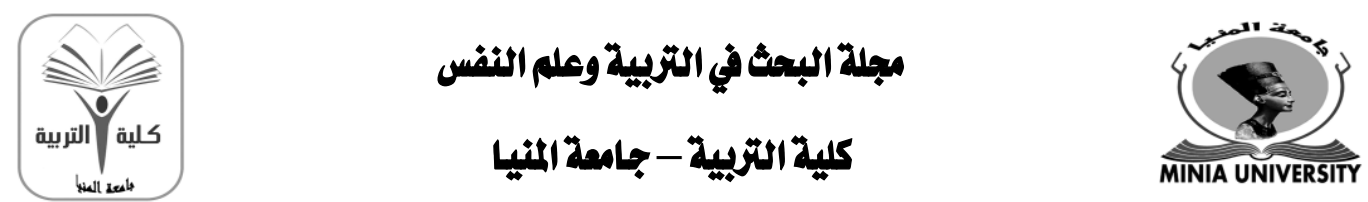

كلية مُعتملة من الميئة القومية لضمان جودة التمليم

Safont \& Compoy (2002) stated that through this technique, students will train various skills such as: listening, analysis, and speech processing and production. Overall, engaging learners in a shadowing task can assist some basic skills, particularly the listening skill.

Shadowing can be a paramount exercise for language learners to evolve their speaking skill. For instance, Wiltshier (2007: 501) stated that "it provided them with a chance to successfully practice speaking English', Thus, the learners will be able to communicate, express opinions, and convey messages effectively. In addition, he claimed that shadowing can be effective not only for listening and speaking abilities, but also for reading. Accordingly, learners can better understand what they read when they are involved in a shadowing task prior to reading, as well as they can adjust their reading toward the teacher's reading. Moreover, they can avoid mispronunciation and hesitation when enunciating some words. In particular, Jullian (2012) asserted that shadowing is a very efficient technique "to get good at speaking".

Reviewing previous related studies, there are various studies that examine the positive effects of shadow techniques in developing language skills and improving students' low level of language proficiency (e.g, Hamada (2016), Masakazu \& Lixia (2017), Commander \& de Guerrero (2016), Yavari \& Shafiee (2019)). But there are fewer studies that used shadowing technique in the field of professional development (e.g, Bristol, Esnard \& Brown (2015), Barahona (2017), Wennergren (2016)). Consequently, it could be useful to benefit from shadowing in helping teachers to get rid of their problems and difficulties considered teaching demands.

12. Method of the research

Participants of the research

Thirty male and female prospective teachers who studied in Diploma, were chosen voluntarily as an experimental group from Hurghada Faculty of Education as the participants of the present

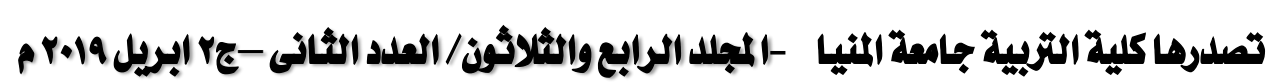

gamel_abdo59@yahoo.com

http://ms.minia.edu.eg/edu/journal.aspx 


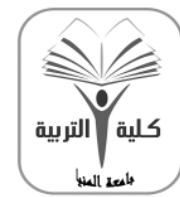

مبلة البعث في التربية وملم النفس

كلية التربية - جامعة المنيا

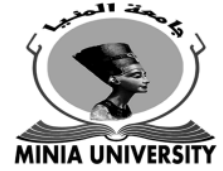

كالية مُعتعدة من الهيئة القومية لشعان جودة التعليم

research. They were instructed through the shadowing video based program.

Design of the research

The research adopted the quasi-experiment of "one-group pretest-posttest design". The one-group pretest-posttest design involved a single group that is pretest $(\mathrm{O})$, exposed to a treatment $(\mathrm{X})$ and post tested $(\mathrm{O})$.

Instruments

\section{Teaching skills observation sheet}

For the purpose of the research, the researcher designed an observation sheet to assess prospective teachers' performance of teaching skills. Designing the observation sheet went through the following procedures:

- Reviewing literature and previous studies related to English language teaching skills.

- Preparing a list of teaching skills. The list consisted of 20 teaching sub-skills divided into the following main skills:

$>$ Lesson planning skills included five teaching sub-skills.

$>$ Presentation skills included five teaching sub-skills.

$>$ Classroom management skills which included six teaching sub-skills.

$>$ Evaluation skills which included four teaching sub-skills.

- The list was judged by a panel of jury members specialized in teaching EFL. They were requested to judge its suitability to the sample of the study. In the light of the jury's suggestions the researcher made the necessary changes and prepared the final form of the list.

- Based on the final form of the teaching skills list, the researcher prepared an observation sheet which consisted of 18 items with a scoring scale of five rating scales ranging from1 to 5.

- The reliability of the observation sheet was measured by an inter rater reliability formula. The prospective teachers' performance was recorded and assessed twice; once by the

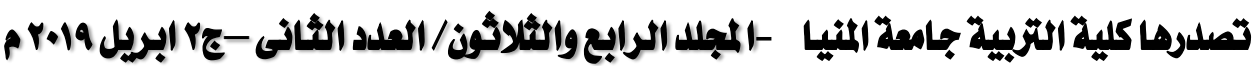



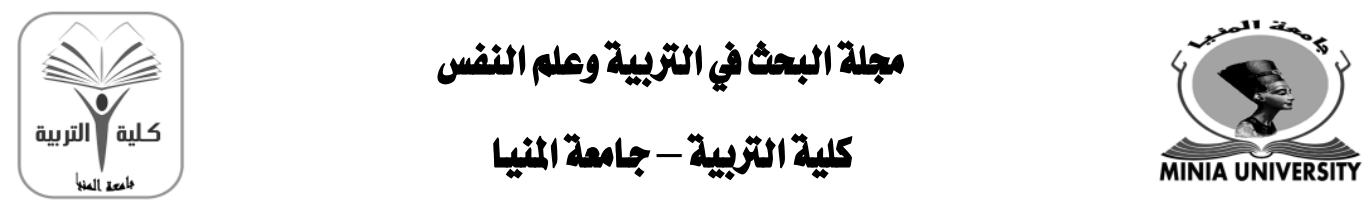

كلية مُعتمدة من الميئة القومية لضمان جودة التمليم

researcher and another by another rater ho has the same qualifications of the researchers. Then inter rater reliability was calculated which indicated a high level of reliability. $\mathbf{R}=\mathbf{. 8 8 2}$

\section{Language proficiency pre/post test}

objectives of the test:

This test was adopted from Ali, E (2001). It was used in the present research to assess prospective teachers' language proficiency level and to see the amount of improvement that might happen as a result of being instructed using video based teaching in shadowing.

- The test included four sections:

I. Section one assessed grammar acquisition (20 MCQ items)

II. Section two assessed vocabulary acquisition ( $20 \mathrm{MCQ}$ items)

III. Section three assessed listening skills which included two parts. Part A has (10 MCQ items); part B has (15 completion items)

IV. Section four assessed reading skills which included two parts. Part A has (20 completion items); part B has (15 MCQ items).

- The instructions of the test are written in English. They are brief, simple to understand and free from any possible ambiguities. They contain information about the objective of the test, time allowed to complete the test and how to record the answers.

- One mark was given for each correct answer.

- The reliability of the test was determined by the test -retest method: The reliability coefficient of the test $(0,775)$ and it was found to be significant at $(0,01)$ level which is acceptable.

3. The shadowing video based program

- The primary objectives of the program were as follows:

$\circ$ providing prospective teachers with the needed teaching skills of English as a foreign language,

$\circ$ providing teachers with opportunities to read about, listen to reflect and discuss issues related to teaching and learning,

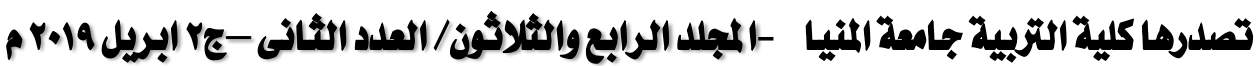




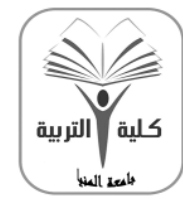

مجلة البعث في التربية وعلم النفس

كلية التربية - جامعة المنيا

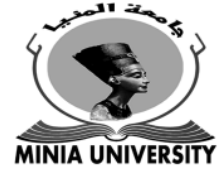

كلية مُعتعدة من الهيئة القومية لشمان جودة التعليم

- developing the prospective teachers' language proficiency in a way that enables them to use English language appropriately in the English class

- The program consisted of five units which dealing with a specific aspect of teaching methodology and classroom practices. The program units covered a variety of areas related to teaching English as a foreign language according to the syllabus of methodology course for diploma which covered the following criteria:

- Teaching language skills (reading - writing - listening speaking - grammar and vocabulary)

- Lesson planning

- Classroom management

- Present different techniques and activities for teaching language skills

- Evaluation

- Each unit consisted of four lessons. Each lesson followed the teaching procedures of shadowing strategy enhanced by videos, which were as follows:

- The videos were selected and prepared according to their appropriateness to the level of the sample, their relatedness to the skills handled in each lesson. Videos of long time were cut into focused videos.

- The teaching strategy used in this program was based on the communicative approach to language teaching which focuses on involving pairs, and small group of prospective teachers in authentic teaching situations and in problem solving activities. This is along with the video-based instruction. Cooperative techniques were also used throughout the program where students worked together in developing audio-visual materials.

- The researcher used the English language as a medium of instruction throughout the program and put a great focus on language skills in the content of the program to develop

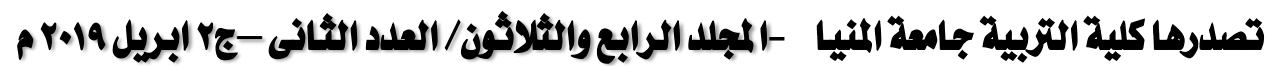



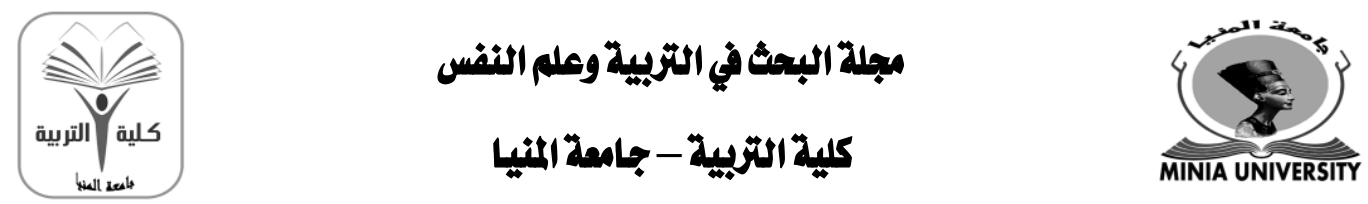

كلية مُعتمدة من الميئة القومية لشمان جودة التمليم

the participants' language abilities and use side by side with teaching abilities.

- A video camera is used to record the teaching practices of the prospective teachers in addition to revising and assessing performance in each lesson.

- The program in its initial form was judged by a panel of jury members of technology and TEFL to ensure its validity to the purpose of the study and its appropriateness to the level of the sample.

- Two lessons of the program were instructed to elicit the difficulties of the program and the problems that may be appeared during the experiment.

The experimental Treatment

According to the research design, the instruments of the research were applied prior to the implementation of the experiment; two weeks before. Then the researcher instructed the shadowing video based program for ten weeks; two sessions a week. Post instruments were applied after finishing the instruction of the program.

\section{Findings and Discussions}

The t-test was used to compare the pre and post-performance of the experimental group to find out the degree of improvement in their teaching skills and language proficiency. The results of the comparison revealed a high degree of improvement in favor of the post-performance.

\section{Testing Hypothesis (1)}

Hypothesis (1) predicted a statistically significant difference between the means of the participants' scores in the pre-post application of the teaching skills observation sheet favoring the post application. Table (1): shows t-test results of pre-post testing of the participants' teaching skills. 

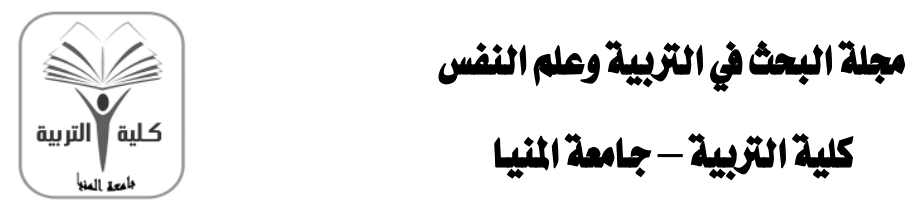

$$
\text { كلية التربية - جامعة المنيا }
$$

MINIA UNIVERSITY

كلية مُعتمدة من الهيئة القومية لضمان جودة التمليم

Table (1)

T-test results of the students in the pre-post observation sheet of teaching skills

\begin{tabular}{|c|c|c|c|c|c|c|c|}
\hline & Administration & Ss & Mean & S D & "t" & Sig. & $\eta^{2}$ \\
\hline \multirow{2}{*}{$\begin{array}{c}\text { Lesson } \\
\text { planning }\end{array}$} & Pre & \multirow{2}{*}{30} & 10.00 & 1.1744 & \multirow{2}{*}{30.867} & \multirow{2}{*}{0.01} & \multirow{2}{*}{1.22} \\
\hline & Post & & 21.433 & 1.6543 & & & \\
\hline \multirow{2}{*}{$\begin{array}{l}\text { Presentation } \\
\text { kills }\end{array}$} & Pre & & 11.700 & 1.4657 & \multirow{2}{*}{29.920} & \multirow{2}{*}{0.01} & \multirow{2}{*}{1.21} \\
\hline & Post & & 22.166 & 1.2340 & & & \\
\hline \multirow{2}{*}{$\begin{array}{l}\text { Classroom } \\
\text { management } \\
\text { skills }\end{array}$} & Pre & & 14.20 & 1.68973 & \multirow{2}{*}{27.050} & \multirow{2}{*}{0.01} & \multirow{2}{*}{1.16} \\
\hline & Post & & 26.233 & 1.75545 & & & \\
\hline \multirow{2}{*}{$\begin{array}{l}\text { Evaluation } \\
\text { skills }\end{array}$} & Pre & & 9.4333 & 1.00630 & \multirow{2}{*}{21.257} & \multirow{2}{*}{0.01} & \multirow{2}{*}{1.05} \\
\hline & Post & & 16.700 & 1.57896 & & & \\
\hline \multirow{2}{*}{ Total } & Pre & & 45.333 & 3.45746 & \multirow{2}{*}{44.193} & \multirow{2}{*}{0.01} & \multirow{2}{*}{1.17} \\
\hline & Post & & 86.533 & 3.75760 & & & \\
\hline
\end{tabular}

Table (1) showed a comparison of mean scores gained by the participants in the pre/post observation sheet of teaching skills. The results showed that the students achieved a high significant degree of improvement in favor of the postperformance. Therefore, the main hypothesis was accepted.

The table also indicated that the shadowing video based program was effective in improving the prospective teachers' teaching skills. The effectiveness of the program was calculated using Etta Squared formula which indicated a high degree of effectiveness.

\section{Testing Hypothesis (2)}

Hypothesis (2) predicted a statistically significant difference between the mean scores of the experimental group in the pre/posttest of language proficiency favoring the post application. Table (2): shows t-test results of the pre/post testing of the prospective teachers' language proficiency. 


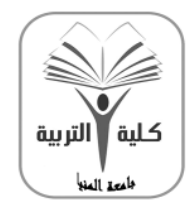

$$
\text { مجلة البعث في التربية وعلم النفس التربية - جامعة المنيا }
$$

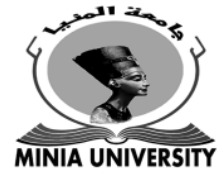

كلية مُتقمدة من الهيئة القومية لضمان جودة التعليم

Table (2)

T-test results of the students' in the pre/posttest of language proficiency

\begin{tabular}{c|c|c|c|c|c|c}
\hline \hline Administration & Ss & Mean & S D & "t" & Sig & $\boldsymbol{\eta}^{2}$ \\
\hline \multirow{2}{*}{ Pre } & \multirow{2}{*}{ Post } & 29.1667 & 6.74196 & & \\
\cline { 3 - 4 } & & 72.7333 & 7.88247 & 23.006 & 0.01 & $\mathbf{1 . 0 5}$ \\
\hline \hline
\end{tabular}

Table (2) showed that there was a statistically significant difference between the mean scores of the experimental group in the pre/posttest of language proficiency. Thus, hypothesis two was accepted.

The table also indicated that the program was effective in improving the prospective teachers' language proficiency level.

3. Testing Hypothesis three

Hypothesis three predicted that there was a statistical correlation between the teaching skills and the language proficiency of the experimental group. Table (3) showed Spearman correlation ratio between the teaching skills and the language proficiency.

Table (3)

Pearson correlation of the students' means scores in the post testing of the teaching

\begin{tabular}{|c|c|c|c|c|c|}
\hline Variable & No. Ss & Mean & SD & $\begin{array}{l}\text { "r" } \\
\text { value }\end{array}$ & significant \\
\hline Teaching skills & \multirow{2}{*}{30} & 86.533 & 3.75760 & \multirow{2}{*}{$.942^{* *}$} & \multirow{2}{*}{0.05} \\
\hline $\begin{array}{l}\text { Language } \\
\text { proficiency }\end{array}$ & & 72.7333 & 7.88247 & & \\
\hline
\end{tabular}
skills and the language proficiency

Table (3) showed that there was a statistically positive correlation between the experimental group's teaching skills and the language proficiency as " $r$ " value $(0.942)$ is significant at $(0.01)$ level. This indicated the improvement of the prospective teachers' teaching skills and language proficiency. Therefore, the third hypothesis was accepted. 


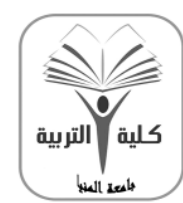

مجلة البعث في التربية وعلم النفس

كلية التربية - جامعة المنيا

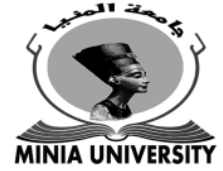

كلية مُعتمدة من الميئة القومية لضمان جودة التمليم

\section{Discussion}

The present research investigated the effectiveness of using a shadowing video-based program in improving prospective teachers' teaching skills and English language proficiency.

Findings of the research are encouraging as they showed that there were statistically significant differences between the mean scores of the experimental group in the pre/post applications of teaching skills and English language proficiency in favor of the post application. This indicated that the experimental group's teaching skills and English language proficiency included in the program have been improved.

The results obtained in the post application indicated that the participants achieved significant improvement in EFL teaching skills after being instructed through the program, which could be due to many reasons. One of these reasons was that the use of shadowing video-based program helped in creating an appropriate and attractive environment for practicing teaching skills. In addition, it encouraged the prospective teachers to engage with the material. The program presented a scaffolding on teaching skills needed by the prospective teachers through presenting and modeling the target teaching skills, give them opportunities to practice teaching in an authentic way and to reflect on the teaching practices introduced.

The participants' scores in the pre-test of language proficiency were unsatisfactory. Before implementing the program, the participants of the research showed low level in their language proficiency as they, in the pre testing, showed low level in vocabulary selection, answering listening comprehension and listening recall, and a moderate level in answering grammar and reading comprehension questions. Therefore, when they studied the program, they had an opportunity to focus more in correcting their lesson plans, grammar and spelling and they have an opportunity to listen to models of language practices. That, in turn, enabled them to get higher scores on the post test of language proficiency.

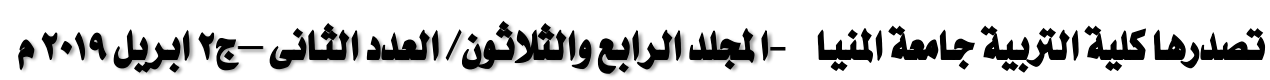

gamel_abdo59@yahoo.com

http://ms.minia.edu.eg/edu/journal.aspx 

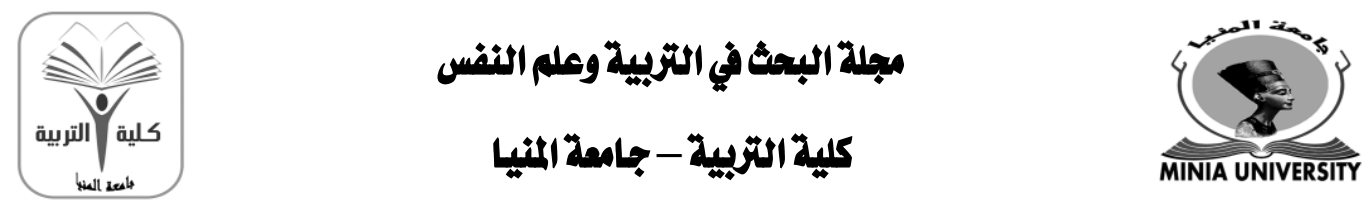

كلية مُعتمدة من الميئة القومية لضمان جودة التمليم

Feedback on prospective teachers' teaching practices and language use was one of the important reasons for the effectiveness of the program, as the trainer had to correct trainees' errors either related to teaching performance or language use. As well, partners' reflection and constructive feedback helped in strengthening good practices and remedying weak ones.

The program also provided them with enough information about the most needed strategies and instructional techniques for teaching any stage of a lesson. This basic information was intended to ensure that learners were fully aware of what they were required to do in order to catch up with the objectives of each session, be equipped with enough information to accomplish the required tasks and hence become more interested in the learned material itself.

The program also helped increasing learners' repertoire of educational terms including those related to the recent trends in education and increasing their acquaintance with the various activities that can be used for teaching the different stages of a lesson. Thus, the SIOP program succeeded in providing trainees with enough theoretical bases for evaluating their own and others' teaching performance. Also, students became aware of how a certain lesson is taught and the possible activities to be used in the different stages of any lesson (Grammar, reading, writing, listening or speaking).

The duration of the program lasted for forty hours in one academic semester (2018/2019), four hours a week. It also might have had its positive effect on the prospective teachers' performance. The researcher believes that the longer the period spent in instruction, the better the chances that training will remain and be transferred to other situations.

The present research agreed with the results of the studies of Onaha (2004), Tamai (2005), Mochizuki (2006), and Suzuki (2007), which showed that shadowing was directly beneficial to improve learning.

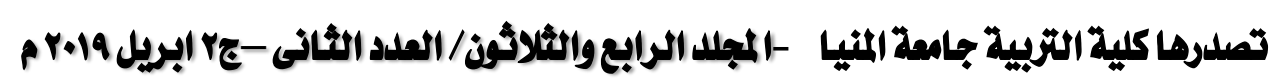

gamel_abdo59@yahoo.com

http://ms.minia.edu.eg/edu/journal.aspx 

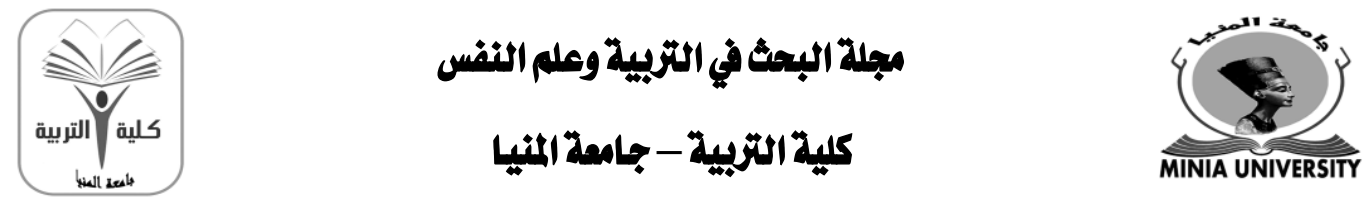

كلية مُعتمدة من الهيئة القومية لضمان جودة التمليم

\section{Conclusion}

Based on the findings of the research, it has become clear that the shadowing video-based program had a statistically significant effect in improving the prospective teachers' teaching skills and English language proficiency.

16. Challenges encountered in conducting the research

The researcher found some challenges while applying the program such as:

1. The insufficiency of time allotted to the implementation process.

2. Most of the participants were shy at the beginning to participate in the implementation process.

3. The insufficiency of the session time.

\section{Recommendations}

The present research was an attempt to investigate the effectiveness of using a shadowing video-based program in improving prospective teachers' teaching skills and English language proficiency.

Based on the results of the research, the following recommendations were made:

1. Using technology to improve the prospective teachers' teaching skills and English language proficiency.

2. Improving the prospective teachers' teaching skills and English language proficiency is a determined necessity for their professional success.

3. The shadowing teaching should be a prerequisite in training both in-service and pre-service teachers so as to help them grow professionally.

4. More attention should be paid to teachers' language proficiency in the teacher preparation programs.

5. Newer methods, models, techniques and strategies should be adopted to encourage the involvement of learners into the act of teaching-learning.

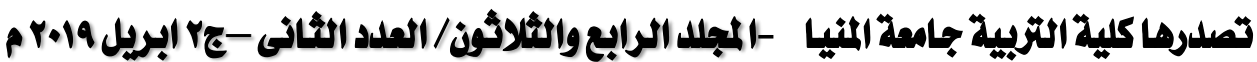




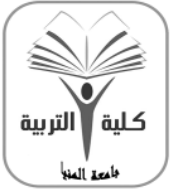

$$
\text { مجالة البعث في التزبية وملم النفس }
$$

$$
\text { كلية التربية - جامعة المنيا }
$$

6. Staff members of the faculties of education should devote more time and effort to link theory to practice in training the prospective teachers of English. 

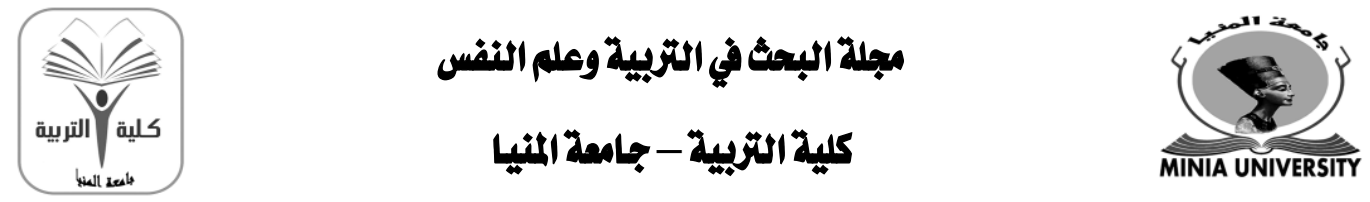

كلية مُعتمدة من الهيئل القومية لضمان جودة التمليم

\section{Reierences}

Abd El-Gawaad, R. (2016). The effectiveness of virtual learning environment in developing teaching efficiency of basic education student teachers of English. PHD Dissertation, Assiut University, Faculty of Education.

Abd El-Menam, M. (2015). The effect of using task based learning approach on developing university student teachers' performance in teaching the English language. PHD Dissertation, Faculty of Education,

Abu El-Enin, H. (2008). The impact of reflective teaching on EFL student teachers' professional development. Master thesis, Faculty of Education.

Akinsola, M. (2014). Assessing pre-service teachers teaching Anxiety. American Journal of Educational Research, 2 (12), 41- 44.

Alderson, J. (2006). Diagnosing Foreign Language Proficiency: The Interface Between Learning and Assessment. A \& C Black.

Algazo, A. (2012). Jordanian teachers' attitudes toward foreign language teaching, language proficiency, and experiental knowledge and their relationship to teachers' classroom practices. PHD dissertation, Yarmouk University,

Ali, E. (2001). Using case-based instruction with senior English education majors in Egypt and the effects on their thinking and attitudes. Ph.D. dissertation. University of Pittsburgh, Ann Arbor, U.S.A.

Al-Mekhlafi, A. (2007). The Development of Prospective EFL Teachers' Specialist Language Competencies in UAE Universities. University of Sharjah Journal for Shari'a Sciences \& Humanities, 4 (1), 1-27.

Altan, M. (2006). Preparation of Foreign language teachers in Turkey: A challenge for the 21st century. Dil Dergisi, 134, 49-54.

Aoki, M. (2013).The Role of Testing Language Proficiency as Part of Teacher Certification. Modern Language Journal, 97 (2), 539540 

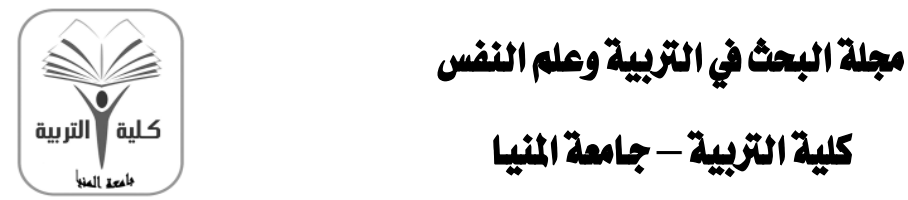

كلية التربية - جامعة المنيا

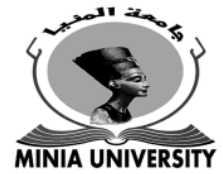

كلية مُعتعدة نن الهيئة القومية لشمان جودة التعليم

Arnold, J. \& Murphey, T. (Eds.). (2013). Meaningful Action: Earl Stevick's Influence on Language Teaching. UK: Cambridge U.P.

Bachman, L. \& Palmer, A. (1996). Language testing in practice. Oxford: oxford university press.

Banegas, D. (2009). Content Knowledge in Teacher Education: Where Professionalisation Lies. ELTED Journal, 12, 44 -51.

Barahona, M. (2017). Exploring Models of Team Teaching in Initial Foreign/Second Language Teacher Education: A Study in Situated Collaboration. Australian Journal of Teacher Education, 42 (12): 144-161

Bristol, L., Esnard, T. \& Brown, L. (2015). In the Shadow/from the Shadow: The Principal as a Reflective Practitioner in Trinidad and Tobag. Journal of Cases in Educational Leadership, 18 (3): $215-227$

Bulger, S., Mohr, D., \& Walls, R. (2002). Stack the deck in favor of your students by using the four aces of effective teaching. Effective Teaching, 5(2).

Butler, G. (2004). What level of English proficiency do elementary school teachers need to attain to teach EFL? Case studies from Korea, Taiwan, and Japan. TESOL Quarterly 38(2): 245-78.

Calandra, B., Brantley-Dias, L., Lee, J., \& Fox, D. (2009). Using video editing to cultivate novice teachers' practice. Journal of Research on Technology in Education, 42(1): 73-94.

Canales, J. (1994). Linking language assessment to classroom practices. Retrieved on Nov 2018 available at http//www.ell.tamucc.edu/files/module

Çetinavcý, U. \& Aysun, Y. (2010). Language Proficiency Level of English Language Teacher Trainees in Turkey. The International Journal of Research in Teacher Education, 1(Special Issue): 26 - 54. 

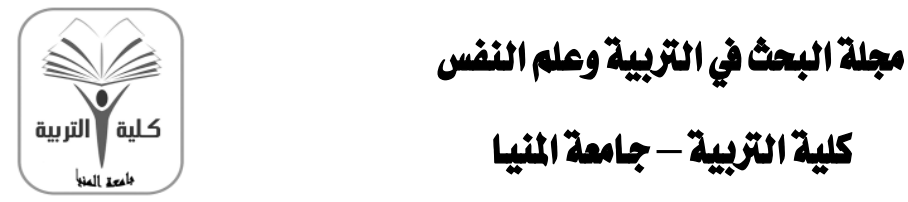

كلية التربية - جامعة المنيا

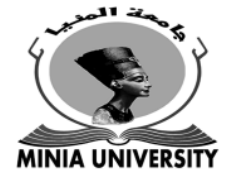

كالية مُعتمدة من الهيئة القومية لشعان جودة التعليم

Commander, M. \& Guerrero, C. (2016). Shadow-Reading: Guidelines for a Socially-Mediated Approach to Reading in the Second/Foreign Language Classroom Reading Matrix: An International Online Journal, 16 (1): 32-48.

Coniam, D., Falvey, P., Xiao, Y. (2017). An Investigation of the Impact on Hong Kong's English Language Teaching Profession of the Language Proficiency Assessment for Teachers of English (LPATE). RELC Journal: A Journal of Language Teaching and Research, 48 (1): 115-133.

Cooper, J. (2011). Classroom teaching skills. Wadsworth, Cengage Learning, Belmont, USA.

Cullen, R. (2002). The use of lesson transcripts for developing teachers' classroom language. In: Trappes-Lomax, H, Ferguson, $\mathrm{G}$ (eds) Language in Language Teacher Education. Amsterdam: John Benjamins Publishing Company, 219 - 38.

Eggen, P., Kamp, D., \& Kauchak, D. (2009). Educational Psychology - Windows on classrooms, $\left(8^{\text {th }}\right.$ ed.). Pearson International edition, New Jersey: Pearson Education.

Fillmore, L., \& Snow, C. (2000). What teachers need to know about language. [On-line]. Available: http://www.cal.org/ericcll/teachers.pdf.

Freeman, D. (2002). The hidden side of the work: teacher knowledge and learning to teach. Language Teaching, 35(1): 1-13.

Freeman, D, Katz, A, Garcia Gomez, P, Burns, A (2015). English-forteaching: rethinking teacher proficiency in the classroom. ELT Journal, 69 (2): 129-39.

Freeman, D. (2016). Educating Second Language Teachers. Oxford: Oxford University Press.

Freeman, D, Katz, A, Le Drean, L, Burns, A, King, S. (2016). ELTeach: Global Implementation Report. Boston, MA: National Geographic Learning.

Fry, H., Ketteridge, S. \& Marshall, A. (2009). Handbook for Teaching and Learning in Higher Education. Routledge: Taylor \& Francis.

Gohar, H. (2014). The effectiveness of a proposed program in electronic assessment driven instruction on developing EFL

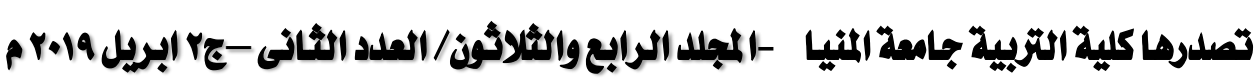

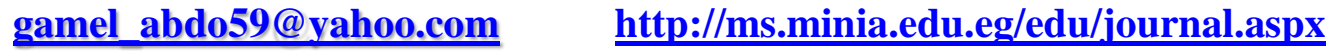




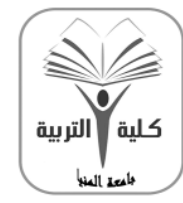

مبلة البعث في التربية وملم النفس

كلية التربية - جامعة المنيا

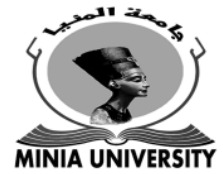

كالية مُعتعدة من الهيئة القومية لشمان جودة التعليم

teaching skills for student teachers at faculties of education. PHD Dissertation, Faculty of Education.

Grosser, M., \& Nel, M. (2013). The Relationship between the Critical Thinking Skills and the Academic Language Proficiency of Prospective Teachers. South African Journal of Education, 33 (2): 639 - 2013

Hamada, Y. (2012). An effective way to improve listening skills through shadowing. The language teacher, 36(1): 3-10. Retrieved fromjalt-publications.org /files/pdfthe_language_teacher/36.1_tlt.pdf

Hamada, Y. (2016). Shadowing: Who Benefits and How? Uncovering a Booming EFL Teaching Technique for Listening Comprehension. Language Teaching Research, 20(1): 35-52.

Hammam, E. (2016). Developing EFL student teachers' classroom performance skills and teaching self-efficacy through co teaching. Master thesis, Faculty of Education.

Hassan, A. (2008). The effect of a training program in language activities classroom management skills for third year English majors on their acquisition and use of these skills. A master thesis, Faculty of Education.

Hatasa, Y. (2011). Nakama 2: Introductory Japanese: Communication, Culture, Context. (Ed). Retrieved from http:// books.google.dz/books?id= FTAWAAAAQBAJ\&pg=PA294\&dq=shadowing improves + speaking + skill \&hl $=$ shadowing $\% 20$ improve $\% 20$

Hunt, B. (2009). Teacher Effectiveness: A Review of the International Literature and Its Relevance for Improving Education in Latin America. Working Paper Series No. 43 Washington, DC: PREAL.

Jennifer F. \& Collins B. (2012). Meet the Needs of English Language Learners Applying Research to Policy and Practice for Teacher Effectiveness. American center for progress. 

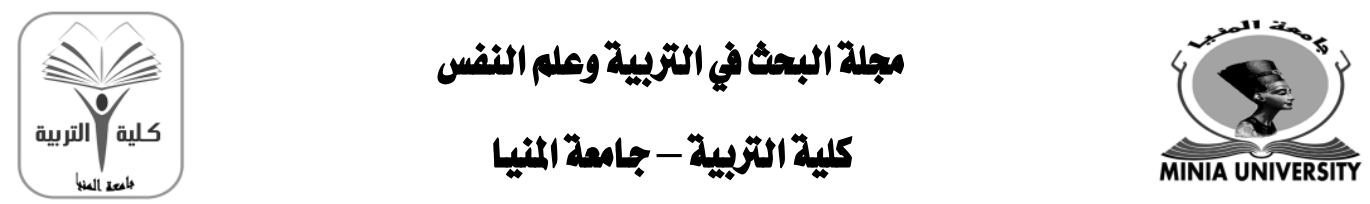

كلية مُعتمدة من الميئة القومية لضمان جودة التمليم

Jullian, K. (2012). English Speaking Practice: How to improve your English Speaking and Fluency: Shadowing (Read along) [Video file]. Retrieved from: $h$ ttp://www.youtube.com/watch? $v=x Y$ S5RgeI6hI Komur, Ş. (2010). Teaching knowledge and teacher competencies: a case study of Turkish pre-service English teachers. Teaching Education, 21 (3), 279-296.

Kyriacou, Ch. (2007). Essential Teaching Skills. Third Edition, United Kingdom, Nelson Thornes Ltd.

Law, B. \& Eckes, M. (2007). Assessment and ESL: An Alternative Approach. Portage \& Main Press.

Macalister, J. (2017). English and Language Teacher Education in Malaysia: An Exploration of the Influences on and Experiences of Pre-Service Teachers. RELC Journal: A Journal of Language Teaching and Research, 48(1): 53 - 66.

Manseur, R. (2015). Exploring the Role of Shadowing in the Development of EFL Learners' Speaking Skill. Faculty of Letters and Foreign Languages, Mohamed Kheider University of Biskra.

Mansour, H. (2015). A program based on self-regulated strategy development approach for developing the teaching and writing performance of EFL student teachers. PHD Dissertation, Faculty of Education.

McBer, H. (2000). Research into Teacher Effectiveness: A Model of Teacher Effectiveness. (Research Report RR216). London: DfEE.

Mochizuki, M. (2006). Exploring the application of shadowing to Japanese education. Audio-Visual Education, 6: 37-53.

Ohio Department of Education (2010). English Language Proficiency Standards.

Center for Curriculum and Assessment, Lau Resource Center.

Onaha, H. (2004). Effect of shadowing and dictation on listening comprehension ability of Japanese EFL learners based on the theory of working memory. JACET Bulletin, 39, 137-148. 

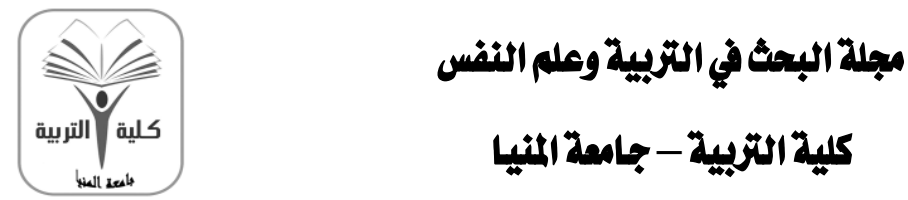

كلية التربية - جامعة المنيا

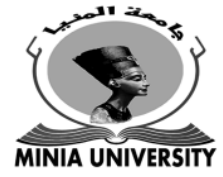

كلية مُعتمدة نن الهيئة القومية لشمان جودة التعليم

Pennington, M, \& Richards, J. (2016). Teacher identity in language teaching: integrating personal, contextual, and professional factors. RELC Journal, 47(1): 5-24.

Pete, B. \& Fogarty, R. (2015). A 21st century measure of effective teaching. Retrieved from http://www.p21.org/newsevents/p21blog/1796-a-21st- century measure-of-effective-teaching.

Philpott, J. (2009). Captivating Your class: Effective Teaching skills. Continuum international publishing Group, New York.

Puri, B. \& Treasaden, I. (2009). Psychiatry: An evidence-based text. Retrieved from https://books.google.dz/books?id= LkbOBQAAQBAJ\&pg=PA180\& dq=puri+treasaden+the + shadowing + tech nique\&hl=fr\&sa $=X \& e i=V V g y V f M I s z t a o 2 U g c A M \& v e d=0 C B 4 Q 6 A E w A A \#$ $v=0$ epage $\&$ q =puri\%20treasaden\%20 the\%20shadowing\%20technique $\& f$

Quigley, B., \& Nyquist, J. (1992). Using video technology to provide feedback to students in performance courses. Communication Education, 41(3): 324 - 334.

Rost, M. \& Wilson, J. (2013). Active Listening: Research and Resources in Language Teaching. Retrieved from http://books.google.dz/books?id=V6EuAgAAQBAJ\&printsec= frontcover $\& h l=f r \# v=o n e p a g e \& q \& f$

Safont, P. \& Compoy, M. (Eds.). (2002). Oral Skills: Resources and Proposals for The Classroom. Retrieved from: http://books.google.dz/books?i=u0KXrQ0XLXUC\& printsec $=$ frontcover $\& \mathrm{hl}=\mathrm{fr} \# \mathrm{v}=$ onepage $\& \mathrm{q} \& \mathrm{f}$

Sherin, M., \& Van, E. (2005). Using video to support teachers' ability to notice classroom interactions. Journal of Technology and Teacher Education, 13 (3): 475 - 491.

Shiki, O., Mori., Y., Kadota, S., \& Yoshida, S. (2010). Exploring differences between shadowing and repeating practices. Annual Review of English Language Education in Japan, 21, 81 - 90.

Sin-wai, C., (2004). A Dictionary of Translation Technology. Retrieved from:

http://books.google.dz/books?id=3gwOFvbxMGcC\&printsec=frontcover\&hl=fr\#v =onepage $\& q \& f$ 

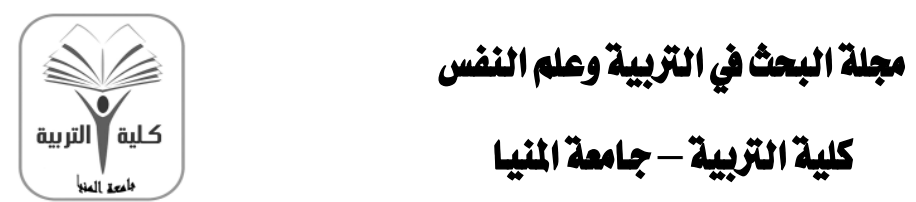

كلية التربية - جامعة المنيا

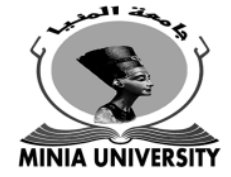

كلية مُعتعدة من الهيئة القومية لشمان جودةالتعليم

Snell-Hornby, M. (Eds.). (1994). Translation Studies anInterdiscipline. Retrieved from

http://books.google.dz/books?id=TCvB2DN6i9kC\&printsec=f rontcover\&hl=fr\# =onepage $\& q \& f$

Snoeyink, R. (2010). Using video self-analysis to improve "withitness" of student teachers. Journal of Digital Learning in Teacher Education, 26(3): 101-110.

Stern, S. (1991).An Integrated Approach to Literature in ESL IEFL "in Teaching English as a second or foreign Language . Boston: Heinle \& Heinle Publishers.

Sumarsih, M. (2017). The Impact of Shadowing Technique on Tertiary EFL Learners' Listening Skill Achievements, International Journal of English Linguistics, 7(5).

Suzuki, K. (2007). Investigation on the instruction for listening comprehension through shadowing. STEP Bulletin, 19, 112 - 124.

Taha, A. (2017).The impact of action research based projects on developing student teachers' EFL teaching knowledge and performance. Master thesis, Faculty of Education.

Tamai, K. (1997). The effectiveness of shadowing and listening process. Current English Studies, 36, 105 - 116.

Tamai, K. (2005). Research on the effect of shadowing as a listening instruction method. Tokyo: Kazama.

Tanaka, M. (2002). Modern interpreting: Where English education and interpreter training intersect. Tsuyaku Honyaku Journal, 1. Retrieved from http://wwwsoc.nii.ac.jp/iais/html/tu hon journal/html/09 tanaka.html

Waxman, Tellez, \& Walberg (2005). Quality teachers for English language learners: A review of the research. The Laboratory for Student Success. Retrieved on May 10, 2018 from: http://files.eric.ed.gov/fulltext/ED508447.pdf

The United Kingdom's international Organization for educational opportunities and cultural relations (2008). Organizational skills profile for teachers. Retrieved at 20/ 8/2018.From:Htp://www. Google.com.eg//?fe_rd=cr\&ei=NyotV7LUFrSs8we8we= the British+Council+teaching+ skills

Toda, T., \& Liu, J. (2007). Basic research for the establishment of a shadowing course. Japanese language education methods, 14(1), 8-9.

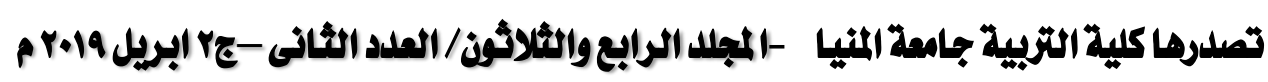

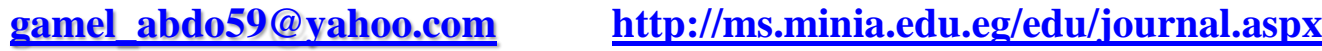




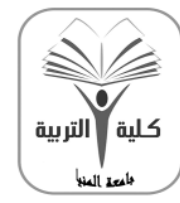

مبلة البعث في التربية وملم النفس

كلية التربية - جامعة المنيا

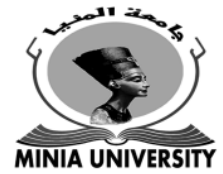

كالية مُعتعدة من الهيئة القومية لشمان جودة التعليم

Tsang, A. (2017). EFL/ESL Teachers' General Language Proficiency and Learners' Engagement. RELC Journal: A Journal of Language Teaching and Research, 48(1): 99 - 113.

Van der M. (2018). Aspects of Academic Language Proficiency of Intermediate Phase Teacher Education Students. South African Journal of Childhood Education, 8(1): 555.

Wang, Z., Tameh, E., \& Nix, A. (2008). Joint shadowing process in urban peer-to-peer radio channels. IEEE Transactions on Vehicular Technology, 57(1): 52 -64.

Wennergren, A. (2016). Teachers as Learners--With a Little Help from a Critical Friend Educational Action Research, 24(2): 260-279

Wiltshier, J. (2007). Shadowing Plus: Stepping Stones to Fluency. The Language Teacher, 31(7), 43-44. Retrieved from: jaltpublications.org/files/pdf/the_language_teacher/07_2007tlt.pdf

Wragg, E. (2005). The Art and Science of Teaching and Learning: The Selected Works of Ted Wragg. London: Routledge Falmer.

Yavari, F. \& Shafiee, S. (2019) Effects of Shadowing and Tracking on Intermediate EFL Learners' Oral Fluency. International Journal of Instruction, 12(1): 869 - 884

Young, J., Freeman, D, Hauck, M., Garcia Gomez, P., \& Papageorgiou, S. (2014) A Design Framework for the ELTeach Program Assessments (ELT Research Report No RR- 13-46). Princeton, NJ: Educational Testing Service. Doi.1002/ets2.12036

Zhang, M., Lundeberg, M. \& Eberhardt, J. (2010). Seeing what you normally don’t see. Phi Delta Kappan, 91(6), 60-65. 